\title{
Az anyai attitűdöt befolyásoló családi tényezők
}

\section{The influence of family factors on maternal attitudes}

\author{
Szerzők: Pachner Orsolya ${ }^{a} \bowtie$, Lendvay Zsófia ${ }^{b}$ \\ a: Pécsi Tudományegyetem Egészségtudományi Kar, Sürgősségi Ellátási és Egészségpedagógiai \\ Intézet, Klinikai Koordinációs és Neveléstudományi Tanszék, b: Napfény Segitő Központ Védőnői \\ Szolgálat
}

Beküldve: 2018. 06. 11.

doi: $10.24365 /$ ef.v59i5.324

Bevezetés: A pozitív anyai hozzáállás, az egészséges anya-magzat kapcsolat, közvetve az anya és a baba lelki egészségének alapja. Az anya viszonyulását magzatához számos tényező, köztük a család jellemzői jelentősen befolyásolhatják. Kutatásunk célja feltérképezni a várandós nők társas támogatottságát, párkapcsolati elégedettségét, hogy milyen összefüggésben állnak ezek a kapcsolati tényezők az anyasághoz való viszonyulásukkal. Az anyai attitûd mellett a várandós nők által észlelt apai attitûd mértékét is vizsgáljuk, illetve a védőnő családot támogató szerepét.

Módszertan: Célcsoportunk 18 év feletti, párkapcsolatban élő várandós nők voltak ( $n=547$ ), átlag életkoruk 28,7 (SD=5,3) év. Saját szerkesztésű kérdőívünk - mely a demográfiai adatokra, anyai és apai attitűdre, védőnővel való együttmúködésre tartalmazott kérdéseket - mellett két standard kérdőívet alkalmaztunk az adatgyüjtés során, a Kapcsolati Elégedettség Skálát és a Társas támogatás kérdőívet. Az alábbi statisztikai módszereket használtuk az adatelemzés során: x2-próba, független mintás t-próba, korreláció analízis (Spearman, Pearson), egyszempontú független mintás varianciaanalízis.

Eredmények: Vizsgálati mintánkban az anyai attitűd független volt a családi állapottól $(p=0,249)$ és a párkapcsolati elégedettségtól ( $r=0,028 ; p=0,507)$, viszont szignifikáns, de elhanyagolható mértékű pozitív összefüggést mutatott a társas támogatás mértékével $(r=0,105 ; p=0,014)$ és a szülővel való kapcsolat erősségével $(r=0,135 ; p<0,001)$. Az első babájukat váró $(p=0,009)$, illetve a babát tervező $(p<0,010)$ nők szignifikánsan magasabb anyai attitűdöt mutattak. Az észlelt apai attitűd jelentősen magasabb volt a házastársi kapcsolatokban $(p=0,003)$, illetve a tervezett várandósság esetén $(p<0,010)$,közepes pozitív korrelációt mutatott a párkapcsolati elégedettséggel $(r=0,642 ; p<0,001)$, és gyenge együttjárást a társas támogatás mértékével $(r=0,229 ; p<0,001)$ valamint az anyai attitűddel $(r=0,292 ; p<0,001)$. A védőnői tanácsadáson való közös részvétel összefüggést mutatott az anya által észlelt magasabb apai attitűddel $(p<0,001)$ és párkapcsolati elégedettséggel $(p=0,002)$.

Következtetések: Tekintettel arra, hogy a tervezett fogantatások esetén magasabb mind az anyai, mind az apai attitǔd, érdemes lenne a családtervezésre nagyobb hangsúlyt fektetni. Az észlelt apai attitűd összefüggésben áll a párkapcsolati elégedettséggel, a védőnői tanácsadáson való közös részvétellel és gyengébb mértékben az anyai attitűddel. Így a párkapcsolat megerősítése, illetve a tanácsadáson való közös részvétel az apai attitűd növelésén keresztül segíthet a pozitív anyai attitűd kialakításában.

Kulcsszavak: várandósság; anyai attitűd; apai attitűd; párkapcsolati elégedettség 
Introduction: Positive maternal attitudes are the basis of a healthy maternal-fetal relationship and indirectly the mother's and baby's mental health. The mother's attitude towards her fetus can be influenced significantly by a number of factors, including family characteristics. Our research aims are mapping the social support and the relationship satisfaction of pregnant women, and the connection between these relationship factors and maternity attitudes. Besides maternal attitudes, we also look at the degree of paternal attitudes felt by pregnant women and the supporting role of the health visitor.

Methods: Our sample consists pregnant women in a relationship over 18 years of age $(n=547)$, with an average age of 28.7 ( $S D=5.3$ ) years. We used two standard questionnaires, the Relationship Satisfaction Scale and the Social Support Questionnaire together with a self-constructed questionnaire for demographic data, maternal and paternal attitudes and cooperation with the health visitor. The used statistical methods were: $\chi 2$-test, independent sample t-test, correlation analysis (Spearman, Pearson), independent samples variance analysis.

Results: In our study maternal attitudes were independent of the marital status ( $p=0.249)$ and the quality of the relationship ( $r=0.028, p=0.507)$. However, it showed a significant, but weak, negligible correlation with social support $(r=0.105 ; p=0.014)$ and the strength of the parent relationship ( $p<0.001 ; r=0.135)$. Women who expected their first baby $(p=0.009)$ and planned pregnancy $(p<0.010)$ showed significantly higher maternal attitudes. The observed paternal attitude was considerably higher in spousal relationships $(p=0.003)$ and in planned pregnancy $(p<0.010)$. There was a moderate positive correlation with relationship satisfaction $(r=0.642 ; p<0.001)$ and poor correlation with the level of social support $(r=0.229, p<0.001)$, as well as with maternal attitudes $(r=0.292 ; p=0.001)$. Joint participation in counselling with the health visitors was associated with higher parental attitudes $(p<0.001)$ and relationship satisfaction $(p=0,002)$.

Discussion: Given that in planned pregnancy both the mother's and father's attitudes were higher, it would be worthwhile to put emphasis on family planning. The perceived paternal attitude is related to relationship satisfaction, counselling with the health visitor together, and weaker related to maternal attitudes. Strengthening the relationship with the partner, and the joint consultation can promote developing a positive maternal attitude by increasing the father's attitude. Keywords: pregnancy; maternal attitudes; paternal attitudes; relationship satisfaction

\section{BEVEZETÉS}

A várandósság idején nemcsak egy új élet fejlődik, hanem a gyermekvállaló pár életében is új szakasz következik. A kilenc hónap során a család felkészül az új tag befogadására, mely szükségképpen az eddigi családi rendszer átrendeződését is igényli. Legnagyobb változást az első gyermek születése hozza.

Számos szakirodalom foglalkozik az anya viselkedésének hatásával a magzati fejlődésre. ${ }^{1,2,3,4}$ Nemcsak az anya egészségmagatartásával, hanem a várandósság alatti és a gyermekágyi időszakban tapasztalt lelki egészség szerepével is.5,6 Tudjuk, hogy a gyermek egészséges lelki fejlődésének alapja az édesanyja lelki egészsége. ${ }^{7} \mathrm{Az}$ édesanya várandósság alatti pozitív attitűdje magzatához és a várandóssághoz hozzájárul a szülést követő pozitív anya-gyermek kapcsolat kialakulásához. ${ }^{8}$ A várandósság alatti anyai attitǔd alatt vizsgálatunkban a várandóssághoz és a magzathoz való pozitív-negatív viszonyulást, valamint az anyai egészségmagatartást értjük. Elképzelésünk szerint a várandós nő pozitív gondolatai, érzései hozzájárulnak a magzata és saját maga egészségének érdekében végzett cselekvések nagyobb gyakoriságához.

Bár az anya-gyermek kapcsolat kiemelt jelentősége vitathatatlan a gyermek fejlődése szempontjából, nem tekinthetünk rá szigetszerúen elkülönült egységként. Az anya és a gyermek - ahogy az anya és a magzat is - a család rendszerén belül kapcsolódik egymáshoz, így a kapcsolat minőségét befolyásolja a család többi tagja, és a családi rendszer jellemzői. ${ }^{9}$ Kiemelt szerepe van a párkapcsolatnak, az édesapa szerepének ebben a rendszerben. Hadházi és Hajdu kutatása rámutat, hogy a 
kisgyermekes nők anyai kompetenciáit befolyásolja a párkapcsolati elégedettség, és az apa gondoskodó attitűdje. $^{10}$ Valószínű, hogy ez a hatás már a várandósság ideje alatt is érvényesül. Már több mint két évtizede felmerült az apák családi szerepvállalásának kérdése, de továbbra is hiányzik az intézményesített, célzott segítségnyújtás számukra. ${ }^{11}$ Hasonlóan az anyai attitűdhöz, az apai attitűdhöz kapcsolódóan is a pozitív gondolatok, érzések, és az édesanyákat támogató, gondoskodó viselkedések meglétét vizsgáltuk.

Kutatásunk célja feltérképezni a várandós nők társas támogatottságát, párkapcsolati elégedettségét, az általuk észlelt apai attitúdöket, valamint hogy milyen kapcsolatban állnak ezek a kapcsolati tényezők az anyasághoz való viszonyulásukkal. Továbbá a védőnő családot támogató szerepét is vizsgáljuk.

\section{MÓDSZEREK}

Kutatásunk kvantitatív és keresztmetszeti vizsgálat volt, melyet 2017 áprilisa és decembere között végeztük kérdőíves módszerrel, elektronikus úton. Nem véletlenszerű, kényelmi mintavételezést alkalmaztunk. A részvétel önkéntes és anonim alapon múködött, a kérdőív online módon a közösségi médiában lett megosztva, a kitöltés kb. 20 percet vett igénybe. A célcsoportunk 18 év feletti, párkapcsolatban élő várandós nők voltak $(n=547) 28,7$ $(S D=5,3)$ év átlag életkorral. Saját szerkesztésű kérdőív mellett két standard kérdőívet alkalmaztunk, a Kapcsolati Elégedettség Skálát ${ }^{12}$ és a Társas támogatás kérdőívet. ${ }^{13}$

A Társas támogatás kérdőívben 4 fokú Likert-skálán szükséges értékelni, hogy mennyire számíthat a felsorolt személyek (szülő, házastárs, élettárs, szomszéd, barát, rokon, egyházi csoport, iskolatárs, munkatárs, gyermek, segítő foglalkozású szakember, egyesület/segítő szervezet) segítségére a kitöltő. Mi specifikusan arra kérdeztünk rá, hogy mennyire támogatják őt a várandósság alatt. A számítások során az összpontszámot vettük figyelembe.

A Kapcsolati Elégedettség Skála hét kérdésen keresztül vizsgálja, hogy a kitöltő mennyire elégedett jelenlegi párkapcsolatával. A válaszokat 5 fokú Likert-skálán kell jelölni, ahol az 1-es érték jelentette az "egyáltalán nem"-et, míg az 5-ös a "teljes mértékben" választ foglalta magában. A 4. és 7. kérdés fordított item. Az elérhető pontszám 7-35 között alakult, a magasabb pontszám nagyobb elégedettséget jelez.

Saját szerkesztésű kérdőívünk kérdéscsoportjai a következők voltak: szocio-demográfiai adatok (életkor, iskolai végzettség, anyagi körülmények, családi állapot, kivel él együtt, gyermekek száma, párkapcsolat tartama), anyai és apai attitűd, védőnővel való együttműködés. Az anyai attitűdöt 15 kijelentésen keresztül mértük, ahol a válaszadók mindegyik állításnál hatfokú skálán jelölték mennyire jellemző az rájuk. A maximálisan elérhető pontszám 90 volt. A kijelentések az anya viselkedését, érzéseit, gondolatait mérték fel, mint például: "Sokat beszélek a magzathoz.", "Sokat tervezgetem a babaszobát.", "Rendszeresen részt veszek a kontrollvizsgálatokon". Az apai attitűdöt szintén a várandós nő töltötte ki, párjára vonatkoztatva a 10 állítást, hasonló hatfokú skálán jelölve az állitással való egyetértés mértékét (max. 60 pont). $\mathrm{Az}$ állítások a viselkedésre, együttmúködésre, törődésre, érzelmekre, gondolatokra összpontosítottak, hasonlóan, mint az anyai attitűd mérésénél. Mindkét skála esetében a magasabb pontszám pozitívabb attitúdöt jelent.

$\mathrm{Az}$ adatok feldolgozása Microsoft Excelben történt, a statisztikai számításokhoz SPSS 22 programcsomagot használtunk. Az adatok elemzéséhez az alábbi statisztikai módszereket alkalmaztuk: $\chi^{2}$-próba, független mintás t-próba, korreláció analízis (Spearman, Pearson), egyszempontú független mintás varianciaanalízis. Az eredményeket $p<0,05$ esetén tekintettük szignifikánsnak.

\section{EREDMÉNYEK}

\section{Várandósság}

A vizsgálati személyek közül 50,5\% az első gyermekét várta. $A$ válaszadók nagy része $(84,6 \%, n=463)$ tervezte a teherbe esést, 54\%-uknak azok közül, akik tervezték, 3 hónapon belül megtörtént a fogantatás.

\section{Párkapcsolat}

A vizsgálatban részt vevő nők 63,1\%-a házasságban élt. Átlagosan 6 éve $(S D=4,1)$ vannak együtt párjuk- 
kal, 52,3\%-nak 1-5 éve tart a kapcsolata. A párkapcsolati elégedettség skála megbízhatósági értéke saját adatainkon jónak bizonyult (Chronbach $\alpha=0,910)$. Mintánkban az átlag pontszám $30,3(S D=4,95)$ volt, tehát a várandós nők jelentős része meg volt elégedve a párkapcsolatával. A házasságban élők ( $M=30,8 ; S D=4,33)$ szignifikánsan $(t=3,121 ; p=0,001)$ elégedettebbek voltak a párkapcsolatukkal, mint az élettársi kapcsolatban élők ( $M=29,3 ; S D=5,88)$. A kitöltők többsége saját megítélése szerint pozitív változást tapasztalt a párkapcsolatában a várandósság ideje alatt, amely független volt a családi állapottól $\left(\chi^{2}=6,955\right.$; $p=0,138)$. [1. ábra]

\section{Társas támogatás}

A várandós nők társas támasz skálán elért összpontszáma átlagosan 27,3 (SD=6,1) pont volt. A legjobban párjukra támaszkodnak, de nagy segítséget biztosítanak számukra a szüleik is $(\mathrm{M}=3,42)$, valamint ahogy a 2. ábrán is látható, rokonaikra hasonló mértékben számíthatnak, mint barátaikra. A szülővel való kapcsolatra egy külön kérdésben is rákérdeztünk, ahol 5 fokú skálán értékelhették annak erősségét. Ahogy a 3. ábrán is látható a várandósok többsége pozitív kapcsolatot ápol a szüleivel.

1. ábra: A párral való viszony várandósság alatti változásának eloszlása ( $n=547)$

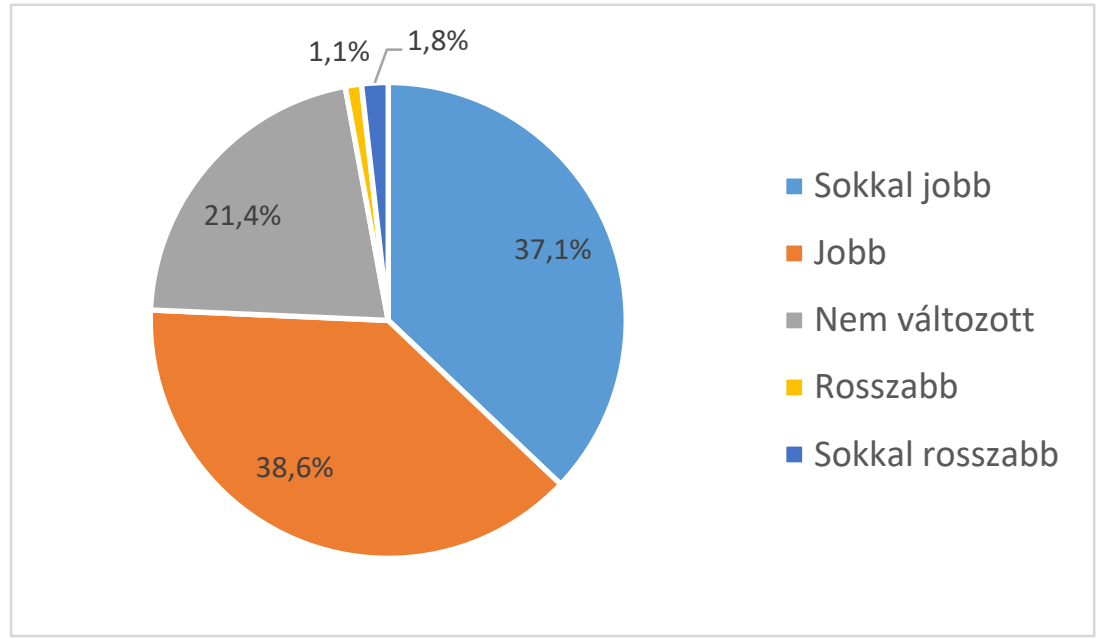

Forrás: saját szerkesztés

2. ábra: A várandósság alatti társas támogatás mértékének átlagértékei a potenciális segitő személyekre vonatkozóan (n=547)

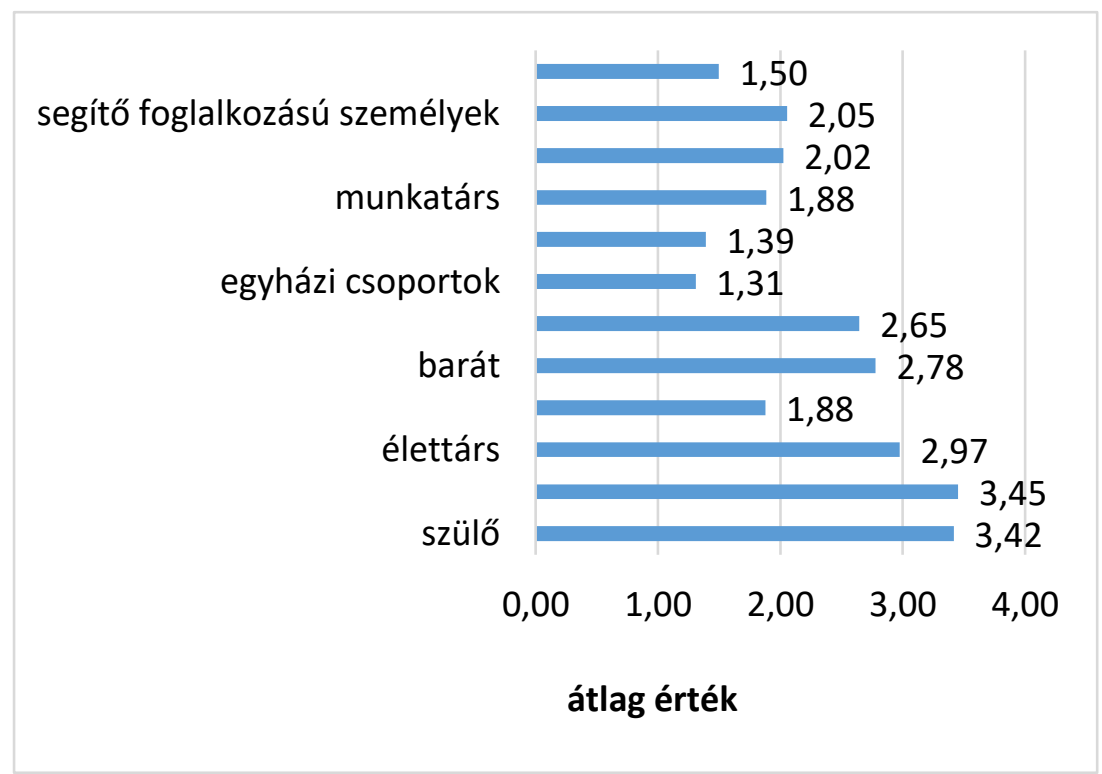

Forrás: saját szerkesztés 
3. ábra: Szülővel való kapcsolat erősségének eloszlása ( $n=547)$

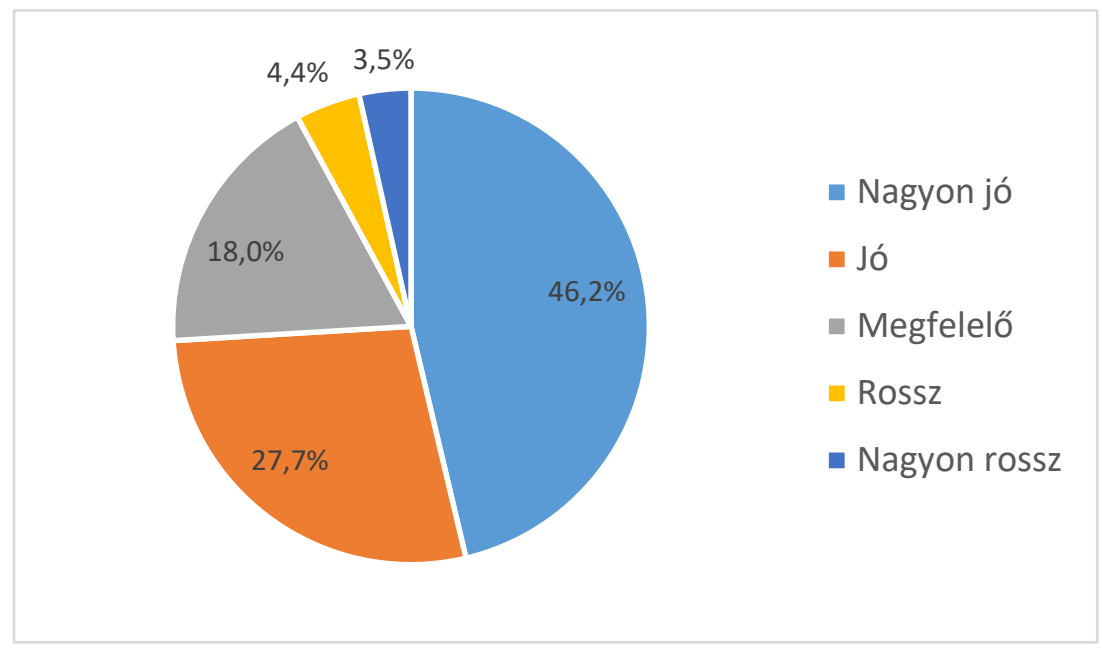

Forrás: saját szerkesztés

Anyai attitűd

A skála megbízhatósági, Cronbach- $\alpha$ értéke 0,68-0,75 között alakult. A számítások során a 15 kijelentéssel való egyetértés mértékének összpontszámát alkalmaztuk (max. 90). A minta átlaga 73,63 (SD=7,51) pont volt, tehát az általunk vizsgált várandós nők csoportjára pozitív anyai attitűd volt jellemző. Csupán a minta 2,2\%-ára, vagyis 12 főre volt jellemző alacsony anyai attitűd, amennyiben a határértéket az átlagtól két szórásnyi eltérésre állapítottuk meg, azaz 58 pontban.

A tervezett várandósság esetén $(M=74,1 ; S D=6,7)$ jelentősen pozitívabb volt az anyai attitűd ( $t=2,659$; $\mathrm{p}<0,010)$, mint a nem várt terhesség esetén $(M=71,0 ; S D=10,3)$.

Vizsgálati mintánkban az anyai attitűd független volt a családi állapottól ( $t=-1,154 ; p=0,249)$ és a párkapcsolati elégedettségtől ( $r=0,028 ; p=0,507)$, szignifikáns, de elhanyagolható mértékű pozitív összefüggést mutatott a társas támogatás mértékével $(r=0,105 ; p=0,014)$ és a szülővel való kapcsolat erősségével $(r=0,135 ; p<0,001)$. Az első gyermeküket váró nők $(M=74,4 ; S D=7,84)$ anyai attitűdje szignifikánsan magasabb volt ( $t=-2,631 ; p=0,009)$, mint a már gyermekes anyák esetében mért érték $(\mathrm{M}=72,7 ; \mathrm{SD}=7,07)$.

\section{Az anya által észlelt apai attitűd}

A várandósok által észlelt apai viszonyulást mérő skála reliabilitása jó, 0,880-as Cronbach- $\alpha$ értéket mutatott. Az átlag pontszám 49,4 (SD=10,03) pont volt, ami alapján megállapítható, hogy a várandósok szerint párjuknak pozitív az apasághoz való hozzáállása. Ebben az esetben a minta 4,8\%-a (26 fő) észlelt az átlagtól jelentősen alacsonyabb apai viszonyulást, amennyiben a határértéket az átlagtól két szórásnyi eltérésre állapítottuk meg, azaz 29 pontban.

A tervezett várandósság ( $M=50,4 ; S D=8,93)$ esetén ebben a tekintetben is szignifikánsan pozitívabb attitűdöt mértünk ( $t=5,549 ; p<0,010)$, mint a nem tervezett terhességek esetén ( $M=44,0 ; S D=13,51)$. $A z$ észlelt apai attitúd jelentősen ( $t=3,020 ; p=0,003)$ magasabb volt a házastársi kapcsolatokban $(M=50,4 ; S D=9,02)$, mint az élettársiakban $(M=47,6$; $\mathrm{SD}=11,3)$; közepes pozitív korrelációt mutatott a párkapcsolati elégedettséggel $(r=0,642 ; p<0,001)$, és gyenge együttjárást a társas támogatás mértékével $(r=0,229 ; p<0,001)$. Nem volt különbség $(t=-1,650 ; p=0,099)$ az észlelt apai attitűdben az első vagy többedik gyermeket váró nők között. Az anyai és apai attitűd gyenge együttjárást mutatott $(r=0,292 ; p<0,001)$.

\section{Védőnő szerepe}

A védőnő különböző feladataival kapcsolatos elégedettségre is rákérdeztünk. Ebből kiemelnénk a családi életre, szülői szerepre való felkészítést, amit a várandósok közel egyharmada (37,1\%) szerint teljes mértékben elvégez a védőnőjük, 14,7\% viszont nem elégedett (egyáltalán nem/kevésbé). 
Nyitott kérdésünkre, miszerint miben szorulnak több segítségre, 7,5\% a lelki támogatást nevezte meg.

Megkérdeztük a várandós nőket, milyen gyakran kíséri el őket párjuk védőnői tanácsadásra. Ahogy a 4. ábra is jól szemlélteti, jelentősen kevés azoknak a pároknak a száma, akik mindig közösen járnak a védőnő által tartott folyamatos, célzott, szükség szerinti gondozásra.

A közös tanácsadás gyakorisága összefüggést mutatott az anya által észlelt apai attitűddel $(F(4 ; 542)=13,824 ; \quad p<0,001)$ és a párkapcsolati elégedettséggel is $(F(4 ; 542)=4,340 ; p=0,002)$. Azok, akiket soha nem kísér el a párjuk a védőnői tanácsadásra szignifikánsan alacsonyabb apai attitűdöt észleltek, mint azok, akiket elkísér a párjuk bármilyen gyakorisággal. A párkapcsolati elégedettségben hasonlóan azok mutattak alacsonyabb összpontszámot, akiket nem kísér el a párjuk, azokkal szemben, akiket gyakran vagy mindig elkísér.

4. ábra: A párjával közös védönői tanácsadás látogatás gyakoriságának eloszlása ( $n=457)$

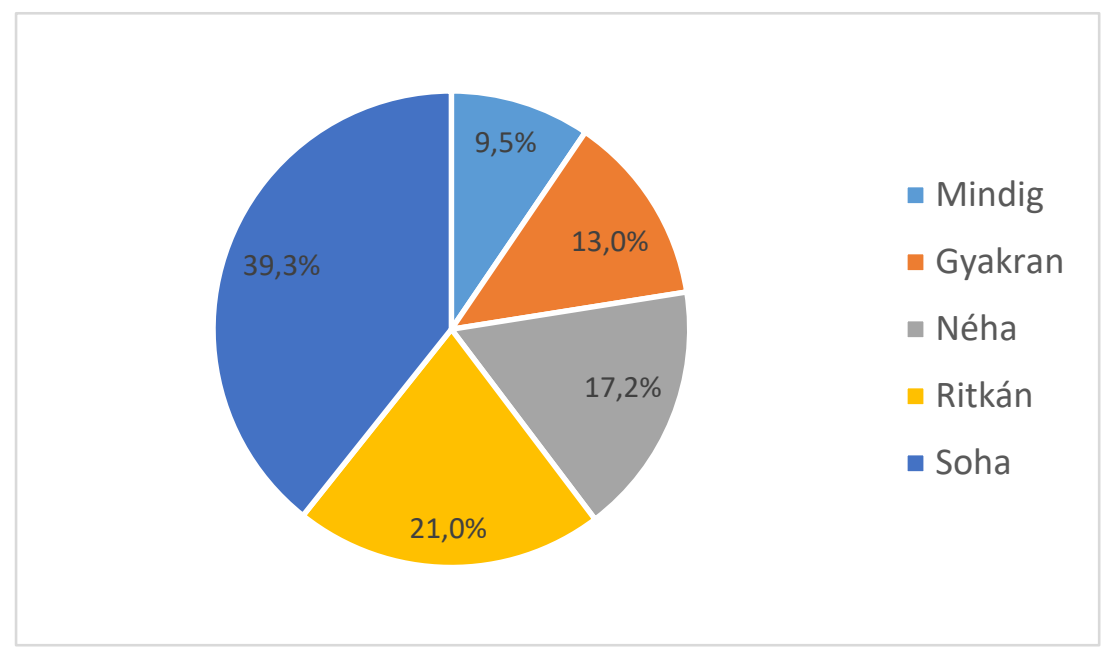

Forrás: saját szerkesztés

\section{MEGBESZÉLÉS}

Kutatásunkban a család, azon belül is főként a párkapcsolat szerepét vizsgáltuk az anyai viszonyulásra. Eredményeink szerint az anyai attitúdre számos olyan tényező hatással van, melyeket mint protektív tényezőket vehetünk figyelembe. Ilyen faktor a várandósság tervezettsége, illetve a terhesség száma. A tervezett, első várandósságok esetén pozitívabb a nők anyasághoz való viszonya. Több kutatás is alátámasztja a nem várt várandósság negatív hatásait mind az anya lelki egészségére, ${ }^{14}$ mind az anya-magzat kapcsolatra. ${ }^{8}$ Úgy gondoljuk, hogy a már gyermekkel rendelkező anyák esetén az alacsonyabb anyai attitǔd inkább az erőforrások megosztására vezethető vissza.

Továbbá a család szerepét alátámasztó eredményeket kaptunk. Bár az anyai attitűd függetlennek bizonyult a családi állapottól, és a párkapcsolati elégedettségtől úgy tűnik, hogy ezek hatása az anya által észlelt apai attitűdben megmutatkozik. A házasságban élő nők, és azok, akik elégedettebbek a párkapcsolatukkal pozitívabb apai viszonyulásról számoltak be, ami gyenge, de pozitív együttjárást mutatott az anyai attitǔddel. Tehát azokra a nőkre, akik párjukon pozitívabb hozzáállást észlelnek, pozitívabb anyai attitûd jellemző. Úgy tûnik, hogy az észlelt apai attitűd és a párkapcsolati elégedettség szoros kapcsolatban állnak egymással. Nem meglepő, hogy a várandós nők akkor elégedettebbek a párkapcsolatukkal, ha párjuk pozitívabb apai viszonyulást mutat. Ez jellemzőbb a házasságban élő párok esetén. Hadházi és Hajdú ${ }^{10}$ kutatása szerint az észlelt apai gondoskodás és a párkapcsolati elégedettség is a baba tervezettségével van összefüggésben, melyet a mi adataink is megerősítenek. ${ }^{10}$ Saját eredményeink alapján is elképzelhető, hogy az észlelt apai attitûd közvetíti a családi állapot hatását az anya-gyermek kapcsolatra, amelyet Andrek és munkatársai igazoltak. ${ }^{15}$ 
Az apai attitűd mellett a szülővel való kapcsolat erőssége elhanyagolható hatással volt az anyai attitűdre, pedig korábbi irodalmi adatok alapján úgy tűnik, hogy nemcsak a gyermekkorban átélt tapasztalatok, hanem a szülővel való kapcsolat jelenlegi minősége is befolyásolja az anyasághoz való hozzáállást. ${ }^{16}$ Eredményeink szerint a társas támogatásnak gyakorlatilag nem volt hatása az anyai attitúd alakulásában.

Lényeges, hogy azok a szakemberek, akik találkoznak a várandós nővel, a családi kapcsolati rendszerrel együtt tekintsenek rá. Saját vizsgálatunkban a szakemberek közül csak a védőnők szerepére tértünk ki. Úgy tûnik, hogy a várandósok többsége elégedett védőnője munkájával, azon belül a családi életre, szülői szerepre való felkészítés minőségével is. De fontos megjegyezni, hogy ezt leggyakrabban az anya egyedül kapja meg, hiszen a várandósok több mint egyharmadát soha nem kíséri el párja a tanácsadásokra. Pedig a védőnői tanácsadáson való közös részvétel összefüggést mutatott az anya által észlelt magasabb apai attitúddel és párkapcsolati elégedettséggel is.

Vizsgálati eredményeinkből levonható következtetéseknek korlátja, hogy mintánk nem reprezentatív. Érdemes lett volna kifejezetten első babájukat váró nőket megkérdezni, hiszen más változások várhatók a még gyermektelen párok vagy a már kisgyermekes szülők családi rendszerében. További limitáció az anyai attitǔd skála alacsony megbízhatósága. A skálában több pozitív, érzelmekkel kapcsolatos állítás kapott helyet, mint „Nagyon örültem, amikor kiderült, hogy babát várok". Emellett viszont négy fordított, negatív állítás is szerepelt, amelyek különböző félelmekhez kapcsolódtak, illetve négy állítás a várandóssággal kapcsolatos egészségmagatartásra kérdezett rá. Valószínúleg ezeket az aspektusokat elkülönült faktorokként lett volna érdemesebb kezelnünk.

\section{KÖVETKEZTETÉSEK}

Kutatásunkban nem a várandósság alatti pszichés patológiák feltárását tűztük ki célul, hanem a várandósság alatti anyai attitűdöt meghatározó tényezők feltérképezését, azok befolyásoló tényezőinek vizsgálatát, kiemelve a környezet szerepét ebben a dinamikus egyensúlyban, hasonlóan Antonovsky egészségfelfogásához. ${ }^{17}$

A pozitív anyai hozzáállás az egészséges anyamagzat kapcsolat, így közvetve az anya és a baba lelki egészségének alapja. A várandós nővel találkozó szakembereknek - így például a védőnőknek fontos támpontot adhat az anya és az apa hozzáállásának felmérése ahhoz, hogy milyen mértékü külső, a családi rendszeren kívüli támogatásra lehet szükségük a szülóknek ebben a fontos életszakaszban.

Mivel a tervezett fogantatások esetén magasabb mind az anyai, mind az apai attitűd, így érdemes lenne a családtervezésre nagyobb hangsúlyt fektetni. A párkapcsolat megerősítése és a védőnői tanácsadáson való közös részvétel segíthet a pozitív anyai viszonyulás kialakulásában. Emellett lényeges az információ alapú tanácsadás mellett a lelki egészségmegőrzést célzó segítő beszélgetések biztosítása a várandósgondozás során.

A jövőben szeretnénk egy longitudinális kutatást végezni, hogy megfigyelhessük a várandósság alatti és a szülés utáni párkapcsolati elégedettség stabilitását. Továbbá felmérnénk, hogy a gyermek születése hogyan befolyásolja a párkapcsolat alakulását a várandósság alatti második és harmadik trimeszterben, valamint a szülés utáni 6 . héten és 6. hónapban.

\section{HIVATKOZÁSOK}

\footnotetext{
${ }^{1}$ Leung, B M Y, Giesbrecht, G F, Letourneau, N, et al. Perinatal nutrition in maternal mental health and child development: Birth of pregnany cohort. Early Human Development. 2016; 93:1-7. doi.org/10.1016/j.earlhumdev.2015.11.007 2 Bloomfield, FH, Spiroski, A-M, Harding J E. Fetal growth factors and fetal nutrition. Seminars in Fetal \& Neonatal Medicine. 2013; 18:118-123. doi: 10.1016/j.siny.2013.03.003

${ }^{3}$ Wang, N, Tikellis, G Sun, C, Pezic, A, et al. The effect of maternal prenatal smoking and alcohol consumption on the placenta-to-birht weight ratio. Placenta. 2014, 35:437-441. doi: 10.1016/j.placenta.2014.04.006
} 
${ }^{4}$ Sussman, D, Lye, S J, Wells, G D. Impact of maternal physical activity on fetal breathing and body movement A review. Early Human Development. 2016, 94:53-56. doi:10.1016/j.earlhumdev.2016.01.006

${ }^{5}$ Szeverényi P. Szülészeti-nőgyógyászati pszichoszomatika. In: Paulin F (editor) Korszerű szülészet-nőgyógyászat. Semmelweis Egyetem Egészségtudományi Kar, Budapest, 2012. pp 125-143.

${ }^{6}$ Antoine C. A terhesség és az anyaság pszichológiája. Saxum, Budapest, 2010.

${ }^{7}$ Vida Á. Anyapszichológia. Kismamablog, 2014.

${ }^{8}$ Pisoni, C, Garofoli, F, Tzialla, C et al. Risk and protective factors in maternal-fetal attachment development. Early Human Development. 2014; 545-546. doi.org/10.1016/S0378-3782(14)50012-6

${ }^{9}$ Székely Zs. Szülés-család-párkapcsolat. Kapocs. 2011;10(1):1-18.

${ }^{10}$ Hadházi É, Hajdú I. Múlt és jelenbeli tapasztalatok összefonódásai a párkapcsolatban és az anyaságban. Psychologia Hungarica. 2014;2(1):23-49.

${ }^{11}$ Győrfi É. Apák és családok. Család Gyermek Ifjúság. 2008; 17(1):48-52.

12 Martos T, Sallay V. A Kapcsolati Elégedettség Skála magyar változatainak (RAS-H) pszichometriai jellemzői. Mentálhigiéné és Pszichoszomatika. 2014; 15(3):245-258. doi: 10.1556/Mental.15.2014.3.6.

${ }^{13}$ Kopp M. Magyar Lelkiállapot. Végeken Alapítvány, Budapest, 1992.

${ }^{14}$ Biaggi, A, Conroy, S, Pawlby, S, et al. Identifying the women at risk of antenatal anxiety and depression: A systematic review. Journal of Affective Disorders. 2016; 191: 62-77. doi: 10.1016/j.jad.2015.11.014

${ }^{15}$ Andrek A, Hadházi É, Kekecs Z. Az anya-magzat kötődést mérő Maternal-Fetal Attachment Scale kérdőív magyar nyelvű adaptálása és felhasználásának lehetőségei az ultrahang kommunikációs vizsgálatok során. Orvosi Hetilap. 2016; 157(20):789-795. doi: 10.1556/650.2016.30426

${ }^{16}$ Stocker A K, Hargitai R. Az anya-magzat kötődés narratív pszichológiai vizsgálata. Pszichológia. 2007; 27(3):239-259.

${ }^{17}$ Karácsony I. Az egészég - Antonovsky salutogenetikus szemléletének tükrében. Sport- és Egészségtudományi Füzetek. 2018; 2(1):32-45. 